\title{
Changes in the Production of Salicylic and Jasmonic Acid in Potato Plants (Solanum tuberosum) as Response to Foliar Application of Biotic and Abiotic Inductors
}

\author{
Esmeralda González-Gallegos, Elan Laredo-Alcalá, Juan Ascacio-Valdés, \\ Diana Jasso de Rodríguez, Francisco Daniel Hernández-Castillo* \\ Departamento de Parasitología Agrícola, Universidad Autónoma Agraria Antonio Narro, Saltillo, México \\ Email: ${ }^{\text {fdanielhc@hotmail.com }}$
}

Received 11 June 2015; accepted 21 July 2015; published 24 July 2015

Copyright (C) 2015 by authors and Scientific Research Publishing Inc.

This work is licensed under the Creative Commons Attribution International License (CC BY). http://creativecommons.org/licenses/by/4.0/

(c) (i) Open Access

\section{Abstract}

An alternative to the use of chemical fungicides is to enhance the defensive response of plants by appropriate stimulation, a phenomenon known as induction of resistance. The aim of this study was to determine the changes of endogen levels of salicylic acid (SA) and jasmonic acid (JA) in potato plants as response to foliar application of biotic and abiotic inductors. Treatments T1 = Best Ultra F (Bacillus spp. $10^{8} \mathrm{cfu} / \mathrm{mL}$ and Pseudomonas fluorescens $10^{8} \mathrm{cfu} / \mathrm{mL}$ ) $0.5 \%$, T2 = FullKover HF (microbial jasmonic acid 1500 ppm) $0.2 \%$, T3 = T1 0.5\% + T2 0.1\%, T4 = Milor $^{\circledR}$ (Chlorothalonil + Metalaxyl) $0.5 \%$ and T5 = control (water) were applied in potato plants. The application of biotic and abiotic inductors improved the SA and JA production in potato plants. The production of salicylic acid in potato plants was observed by application of Bacillus spp. and Pseudomonas fluorescens (T1) and fungicide Milor ${ }^{\circledR}(\mathrm{T} 4)$. The application of T1 Best Ultra F, T2 FullKover HF (microbial JA), T3 (T1 + T2) and T4 Milor ${ }^{\circledR}$ improved the JA production in potato plants.

\section{Keywords}

Salicylic Acid, Jasmonic Acid, Bacillus spp., Pseudomonas fluorescens

\footnotetext{
${ }^{*}$ Corresponding author.
} 


\section{Introduction}

Excessive use of pesticides to control plant diseases is an important problem in the agricultural fields, so it is a priority study for biological control, because the current production systems demand the crop protection by innovative and environmentally methods compatible with sustainable agriculture as an alternative to chemical application [1]. An option is to enhance the natural defensive response of plants through adequate stimulation, a phenomenon known as induced resistance [2], which provides an efficient disease control and increases crop yields [3].

Currently there are two ways to induce resistance, the acquired systemic resistance (ASR) and induced systemic resistance (ISR), which can be differentiated by the nature and regulatory paths of the inductor (also called elicitor) [4]. Salicylic acid is a plant hormone that acts as a marker and regulator of plant responses against pathogens and abiotic stress is the molecule involved in ASR pathways [5]. ASR is activated after infection by a pathogen and is characterized by a hypersensitive reaction, local and systemic increase of endogenous SA levels in the plant, and by the production of pathogenesis-related proteins (PR) [6]. Most of the PR proteins are hydrolases, as glucanases (PR-2), chitinase (PR-3), peroxidases (PR-9), defensins (PR-12), thionins (PR-13) and lipid transfer proteins (PR-14) [7]. In plants, the SA biosynthesis is from the shikimate-phenylpropanoids pathway; SA is synthesized from phenylalanine by action of the phenylalanine ammonia lyase enzyme [8]. It has been found that the exogenous application of SA in plants induces stress tolerance, increases the biological response against salinity and extreme temperatures, modifies the concentrations of antioxidants, nutrients and chlorophyll [9] and increases the protection against pathogen attack [10]; defense is related to the attack mode and form of obtaining nutrients by the pathogen (biotrophs or necrotrophs) [11]. According to studies in Arabidopsis thalia$n a$, defense against biotrophic pathogens usually involves dependent signaling of SA, while the induced defense against herbivorous insects and necrotrophic pathogens depend of JA [12].

It has been reported that ISR (another type of resistance) is effective against viral, bacterial and fungal diseases, is dependent of JA signaling and occurs when the plant roots are colonized by some nonpathogenic rhizobacteria or herbivores insect damage [13]. ISR has many similarities with ASR, and provides resistance in uninfected plant parts against pathogens. In plants, JA is synthesized from linolenic acid released from lipid membranes and converted into JA. JA synthesis can be also activated by herbivores, (tissues and leaves damages), and injuries caused by mechanical damage. JA induces trichomes formation on leaves, which confer protection to the leaf, another essential role of JA in the immunity activation against pathogens that feed on dead tissues, such as some necrotrophic fungi or bacteria [12]. In plants, the resistance against pathogenic infection can be improved by biotic and abiotic treatments, also called inductors. The biotic inductors include: necrotrophs and rhizobacteria infection, such as Bacillus, Streptomyces, Pseudomonas, Burkholderia and Agrobacterium, non-pathogenic microorganisms, such as Trichoderma [14] [15]. The abiotic inductors include chemical products or molecules as responsible of disease resistance signaling [16].

The aim of this study was to determinate the changes of endogen levels of SA and JA in potato plants as a response to foliar application of biotic and abiotic inductors.

\section{Materials and Methods}

\subsection{Potato Plants}

Potato minituber var alpha were seeded in plastic packages containing a mixture of peat-most and forest land (1:1), the cultures were kept under greenhouse conditions at the Universidad Autónoma Agraria Antonio Narro, Saltillo, Coahuila, México. When the plants reached 30 days old the treatments application was carried out.

\subsection{Treatments and Sampling}

The biological treatments evaluated were provided by the company Green Corp Biorganiks of México and consisted of: T1 = Best Ultra F (Bacillus spp. $10^{8} \mathrm{cfu} / \mathrm{mL}$ and Pseudomonas fluorescens $10^{8} \mathrm{cfu} / \mathrm{mL}$ ) concentration $0.5 \%, \mathrm{~T} 2=$ FullKover HF (aqueous solution of microbial origin jasmonic acid $1500 \mathrm{ppm}$ ) $0.2 \%$ and $\mathrm{T} 3=\mathrm{mix}$ T1 Best Ultra F 0.5\% + T2 FullKover HF 0.1\%; T4 = Milor ${ }^{\circledR}$ (Chlorothalonil + Metalaxyl) $0.5 \%$ and T5 = absolute control (water). Application was made by spraying on the foliage using a hand sprayer. Samples were collected at $0,1,3,6,12,24$ and $48 \mathrm{~h}$ after treatment application, time 0 was collected before application. The samples were lyophilized, macerated and stored at $-20^{\circ} \mathrm{C}$ until use. 


\subsection{Quantification of SA}

To extract SA, $50 \mathrm{mg}$ of macerated tissue were placed in Eppendorf tubes and $1 \mathrm{~mL}$ of extraction solution was added (10\% methanol: $1 \%$ acetic acid: $89 \%$ distilled water), tubes were stirred by vortex during $15 \mathrm{sec}$ and then sonic vibration was used. Tubes were centrifuged at 13,000 rpm by $10 \mathrm{~min}$, the supernatant was recovered, filtered through $0.45 \mu \mathrm{m}$ nylon membrane and placed in a new tube. Quantification of SA was performed using an Agilent 1120 LC chromatography system with UV detector, separation was performed on a Agilent $4.6 \times 150$ $\mathrm{mm}$ C18 5 um column at $30^{\circ} \mathrm{C}$. Mobile phases were $50 \%$ phase A $(94.9 \%$ water: $5 \%$ acetonitrile: $0.1 \%$ formic acid) and $50 \%$ phase B (5\% water: $94.9 \%$ acetonitrile: $0.1 \%$ formic acid) [17], flow rate $0.6 \mathrm{~mL} / \mathrm{min}$ by $12 \mathrm{~min}$ at $250 \mathrm{~nm}$ wavelength, sample injection $20 \mu \mathrm{L}$. The hormone was determined on three independent samples from each sampling time and treatment. The concentration was calculated using a calibration curve with standard salicylic acid.

\subsection{Quantification of JA}

To extract JA, $100 \mathrm{mg}$ of macerated tissue were placed in Eppendorf tubes and $450 \mu \mathrm{L}$ of extraction solution were added (95\% methanol: 5\% ethyl acetate), tubes were stirred by vortex during 15 sec and then sonic vibration was used. Tubes were centrifuged at 13,000 rpm by $10 \mathrm{~min}$, the supernatant was recovered, filtered through $0.45 \mu \mathrm{m}$ nylon membrane and placed in glass vial. Solvent was evaporated in an oven at $50^{\circ} \mathrm{C}$ and the residue was resuspended in $1 \mathrm{~mL}$ of mobile phase (60\% methanol: $40 \%$ water: $1 \%$ acetic acid) [18]. Quantification of JA was performed using a HPLC equipment with HP Ultraviolet detector HP7985A, mobile phase was $60 \%$ methanol: $40 \%$ water with $1 \%$ acetic acid. Flow rate was $0.85 \mathrm{~mL} / \mathrm{min}$ using a Hypersil ODS column of $4.6 \mathrm{~mm}$ $\times 25 \mathrm{~cm} \times 5 \mu \mathrm{m}$, JA concentration was determined at $295 \mathrm{~nm}$ during $15 \mathrm{~min}$. Samples were analyzed in duplicate and the JA concentration was calculated using a calibration curve with jasmonic acid standard.

The experiment was carried out only one time in a randomized experimental design, with three replicates per treatment in each time. Data were analyzed using ANOVA and with Tukey test, 0.5 significance.

\section{Results and Discussion}

\subsection{Quantification of SA}

The results shown significant differences between treatments in each sampling time analyzed separately by ANOVA. SA concentration in potato plants it was between 3.68 and $114.02 \mu \mathrm{g} / \mathrm{g}$ dry weight (DW) during the experiment. In the first hour T4 $\left(\right.$ Milor $^{\mathbb{B}}$ ) was statistically different from the control with $112.05 \mu \mathrm{g} / \mathrm{g}$ DW (492\% more than control), however, this value decreased from $3 \mathrm{~h}$ to reach statistically similar levels to the control. T1 (Best Ultra F) increased significantly the SA concentration at $3 \mathrm{~h}$ reaching $114.02 \mu \mathrm{g} / \mathrm{g}$. DW (469\% more than control), the results are shown in the Figure 1. T1, T4 and control did not show significant differences between them at $6 \mathrm{~h}$, but this treatment did show significant differences compared to other treatments. There are no significant differences at 12, 24 and $48 \mathrm{~h}$ for the SA concentration in the treated plants compared with the control.

$\mathrm{T} 4$ (Milor ${ }^{\circledR}$ ) is a mixture of fungicides, Metalaxyl with systemic action and Chlorothalonil with contact action, it is widely used to control diseases caused by oomycetes. In this study it was demonstrated the protectant effect and the potential as defense mechanism activator of Milor ${ }^{\circledR}$ by SA accumulation. It is known that ASR activation is given by abiotic elicitors, such as chemicals products that interact with signaling pathways associated with plants resistance stimulating their defenses, also have a direct negative effect on the pathogen. For example, the fungicide Probenazole induces ASR in Arabidopsis by signaling and accumulation of SA [19]; the herbicides Acifluorfen and Paraquat induce ASR against Colletotrichum lagenarium on cucumber plants [20].

As for T1 (Best Ultra F) containing spores of Bacillus spp. and P. fluorescens, a significant increase was observed in the production of SA $3 \mathrm{~h}$ after application, which coincides with the results reported by Segarra et al. [21] by Trichoderma asperellum spores inoculation in cucumber plants, activating the systemic resistance to Pseudomonas syringae pv. lachrymans, where the highest SA production was detected at the same time reported in this study. Best Ultra F containing $P$. fluorescens, a bacterium that has been reported as ISR activator, effective against different types of pathogens [22]. Saikia et al. [23] reported values up to $2000 \mathrm{ng} / \mathrm{g}$ fresh weight of SA in chickpea plants treated with different strains of $P$. fluorescens. This can be attributed to different mechanisms that have been suggested for the pathogens control with resistance induction in plants by $P$. fluorescens that include the production of HCN, ammonium, antibiotics, siderophores and volatile compounds. Siderophores, 


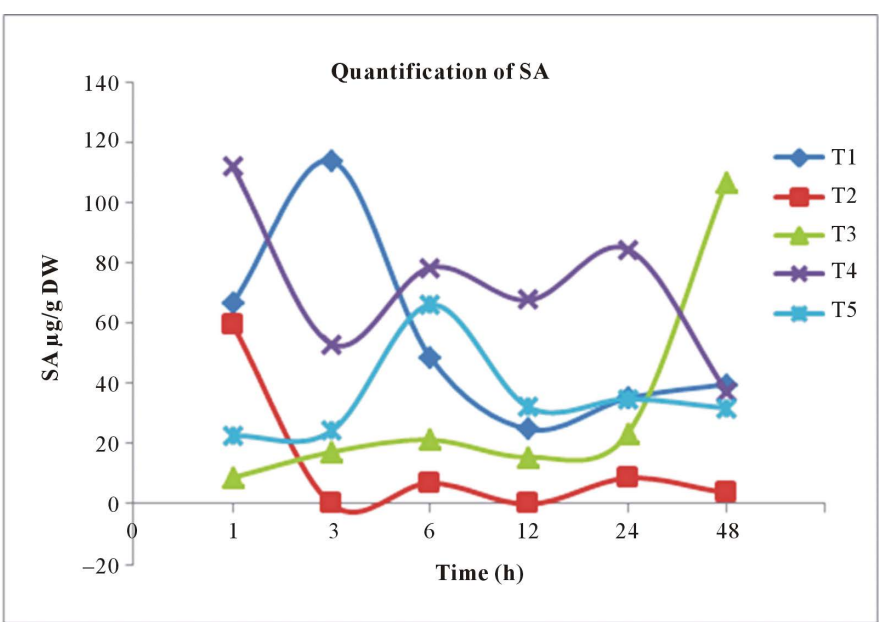

Figure 1. SA production in potato leaves. T1 = Best Ultra F (Bacillus spp. and $P$. fluorescens), T2 = FullKover HF (JA 1500 ppm), T3 = $\mathrm{T} 1+\mathrm{T} 2, \mathrm{~T} 4=$ Milor $^{\circledR}$ (chlorothalonil + metalaxyl) and T5 = control (water).

particularly SA, are involved in the resistance induction in plants [24], but when P. fluorescens is applied in plants is difficult to establish if the SA is produced by the plant or bacteria, because free SA generated locally or systemically is transferred to other tissues throughout the phloem [23]. Chen et al. [25] mention that SA produced by $P$. fluorescens cannot be correlated with the ISR activity, ISR is activated by rhizobacteria and does not require SA because is JA and ethylene dependent [26].

T2 (FullKover HF) containing JA of microbial origin did not induce significant increase of SA compared to control, this can be explained by the fact that JA is the ISR messenger. When ISR is activated, it is characterized by an accumulation of JA, therefore, exogenous application of JA in plants should increase the JA concentration, but not SA concentration, as was observed in this study.

On the other hand, T3 formulated with Bacillus spp., $P$. fluorescens and JA (T1 + T2) induced a time delay for the JA production, this could be attributed to a possible antagonistic interaction of these compounds. It is known that both, SA and JA have a cross signaling, both pathways are mutually antagonistic (Kunkel and Brooks [27]). Similarly, Niki et al. [28] have reported that the SA application in tomato leaves blocks the JA biosynthesis and SA production is inhibited by JA in transgenic tobacco plants; thus, the SA and JA production is inhibited antagonistically by JA and SA, respectively.

\subsection{Quantification of JA}

No JA levels were detected in the control, only in treated plants. The maximum concentrations were obtained at $1 \mathrm{~h}(1572.18 \mu \mathrm{g} / \mathrm{g} \mathrm{DW})$ and $3 \mathrm{~h}\left(569.28 \mu \mathrm{g} / \mathrm{g}\right.$ DW) with T4 (Milor $\left.{ }^{\circledR}\right)$. All treatments, except the control had similar JA levels at 6 h, T1 (Best Ultra F) reached 550.02, T2 (FullKover HF) 833.32, T3 (T1 + T2) 562.48 and T4 (Milor $^{\circledR}$ ) $529.62 \mu \mathrm{g} / \mathrm{g}$ DW. T4 (Milor ${ }^{\circledR}$ ) was the only that kept the JA production at 12, 24 and $48 \mathrm{~h}$ (Figure 2).

JA is the ISR messenger, in plants the level of this hormone depends on the tissue, cell type, development stage and response to different environmental stimuli [29], JA induces the expression of certain genes when is exogenously applied and is accumulated in vegetal tissues after traumatic injury or treatment with inducers, such as T2 FullKover HF (microbial JA solution). Similarly, the JA production using T1 Best Ultra F (Bacillus spp., and $P$. fluorescens) and T3 $(\mathrm{T} 1+\mathrm{T} 2)$ is attributed to both treatments containing Bacillus. It has been demonstrated that B. amyloliquefaciens, B. subtilis, B. pasteurii, B. cereus, B. pumilus, B. mycoides and B. sphaericus are able to elicit and activate ISR increasing the biochemical compounds levels related with this defense [15] [30]. Furthermore it has been reported that some fluorescent Pseudomonas species can induce systemic resistance in plants [14].

T4 Milor ${ }^{\circledR}$ induced in the plant JA production at all times (Figure 2), its ability to induce the SA (above mentioned) and JA production in plants, it is probably because the abiotic inductors, such as chemical products, act in one or several points of the pathways involved in disease resistance [16]. The effect of the presence of both 


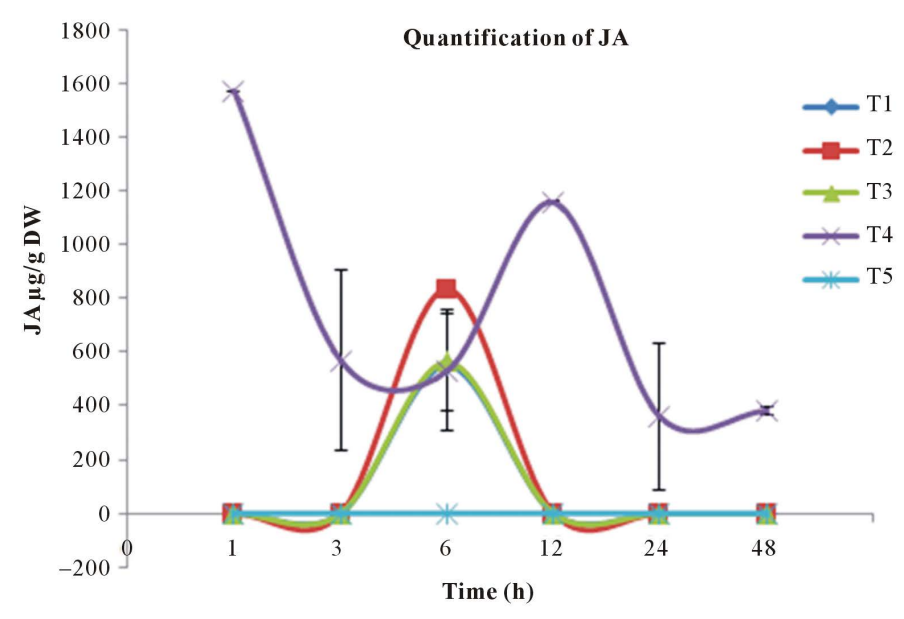

Figure 2. JA production in potato leaves. T1 = Best Ultra F (Bacillus spp. and $P$. fluorescens), T2 = FullKover HF (JA 1500 ppm), T3 = T1 $+\mathrm{T} 2, \mathrm{~T} 4=$ Milor $^{\circledR}($ chlorothalonil + metalaxyl $)$ and $\mathrm{T} 5=$ control (water).

signals by the production of SA and JA, can be explained by a possible crosstalk that is still not entirely clear and that generates a synergistic interaction between these hormones, this synergism depends on the combination and concentrations used [31].

Although the experiment was performed once, the results show the potential use of Bacillus spp., $P$. fluorescens and JA of microbial origin from formulated products to induce resistance in plants as a strategy in the management of diseases and reducing levels of environmental pollution caused by the use of conventional pesticides.

\section{Conclusion}

The application of biotic and abiotic inductors improved the SA and JA production in potato plants. The application of T1 Best Ultra F (Bacillus spp. and Pseudomonas fluorescens) and T4 Milor ${ }^{\circledR}$ improved the SA production in potato plants. The application of T1 Best Ultra F, T2 FullKover HF (microbial JA), T3 (T1 + T2) and T4 Milor ${ }^{\circledR}$ improved the JA production in potato plants.

\section{Acknowledgements}

E. González-Gallegos wants to thank CONACYT for the scholarship assigned to this postgraduate study in the program of Agricultural Parasitology, UAAAN. Authors thank the commercial products provided by the company Green Corp Biorganiks of México.

\section{References}

[1] Kuc, J. (2001) Concepts and Direction of Induced Systemic Resistance in Plants and Its Application. European Journal of Plant Pathology, 107, 7-12. http://dx.doi.org/10.1023/A:1008718824105

[2] Al-Mughrabi, K.I. (2008) Salicylic Acid Induces Resistance in Potatoes against Rhizoctonia solani, the Cause of Black Scurf and Stem Canker. International Journal of Biological Chemistry, 2, 14-25. http://dx.doi.org/10.3923/ijbc.2008.14.25

[3] Abd-El-Kareem, F., Abd, M.A. and El-Mohhamedy, R.S.R. (2001) Induced Resistance in Potato Plants for Controlling Late Blight Disease under Field Conditions. Egyptian Journal of Phytopathology, 29, 29-41.

[4] Kunkel, B.N. and Brooks, D.M. (2002) Cross Talk between Signaling Pathways in Pathogen Defense. Current Opinion in Plant Biology, 5, 325-331. http://dx.doi.org/10.1016/S1369-5266(02)00275-3

[5] Mauch-Mani, B. and Métraux, J.P. (1998) Salicylic Acid and Systemic Acquired Resistance to Pathogen Attack. Annals of Botany, 82, 535-540. http://dx.doi.org/10.1006/anbo.1998.0726

[6] Spoel, S.H., Koornneef, A., Claessens, M.C., Korzelius, J.P., Van-Pelt, J.A., Mueller, M.J., Buchala, A.J., Métraux, 
J.P., Brown, R., Kazan, K., Van Loon, L.C., Dong, X. and Pieterse, C.M.J. (2003) NPR1 Modulates Cross-Talk between Salicylate- and Jasmonate-Dependent Defense Pathways through a Novel Function in the Cytosol. The Plant Cell, 15, 760-770. http://dx.doi.org/10.1105/tpc.009159

[7] Díaz-Puentes, L.N. (2009) Interacciones moleculares entre plantas y microorganismos: Saponinas como defensas químicas de las plantas y su tolerancia a los microorganismos. Una Revision Revista: RET. Revista de Estudios Transdisciplinarios, 1, 32-55.

[8] Raskin, I. (1992) Role of Salicylic Acid in Plants. Annual Review of Plant Physiology and Plant Molecular Biology, 43, 439-463. http://dx.doi.org/10.1146/annurev.pp.43.060192.002255

[9] Guzmán-Téllez, E., Montenegro, D.D. and Benavides-Mendoza, A. (2014) Concentration of Salicylic Acid in Tomato Leaves after Foliar Aspersions of This Compound. American Journal of Plant Sciences, 5, 2048-2056. http://dx.doi.org/10.4236/ajps.2014.513220

[10] Wildermuth, M.C., Dewdney, J., Wu, G. and Ausubel, F.M. (2002) Isochorismate Synthase Is Required to Synthesize Salicylic Acid for Plant Defense. Nature, 414, 562-565. http://dx.doi.org/10.1038/35107108

[11] Glazebrook, J. (2005) Contrasting Mechanisms of Defense against Biotrophic and Necrotrophic Pathogens. Annual Review of Phytopathology, 43, 205-227. http://dx.doi.org/10.1146/annurev.phyto.43.040204.135923

[12] Gutjahr, C. and Paszkowski, U. (2009) Weights in the Balance: Jasmonic Acid and Salicylic Acid Signaling in Root-Biotroph Interactions. Molecular Plant-Microbe Interactions, 22, 763-772. http://dx.doi.org/10.1094/mpmi-22-7-0763

[13] Clarke, J.D., Sigrid, M.V., Ledford, H., Ausubel, F.M. and Dong, X. (2000) Roles of Salicylic Acid, Jasmonic Acid, and Ethylene in cpr-Induced Resistance in Arabidopsis. The Plant Cell, 12, 2175-2190. http://dx.doi.org/10.1105/tpc.12.11.2175

[14] Alizadeh, H., Behboudi, K., Ahmadzadeh, M., Javan, N.M., Zamioudis, C., Pieterse, C.M.J. and Bakker, P.A.H.M. (2013) Induced Systemic Resistance in Cucumber and Arabidopsis thaliana by the Combination of Trichoderma harzianumTr6 and Pseudomonas sp. Ps14. Biological Control, 65, 14-23. http://dx.doi.org/10.1016/j.biocontrol.2013.01.009

[15] Akram, W., Anjum, T., Ali, B. and Ahmad, A. (2013) Screening of Native Bacillus Strains to Induce Systemic Resistance in Tomato Plants against Fusarium Wilt in Split Root System and Its Field Applications. International Journal of Agriculture and Biology, 15, 1289-1294.

[16] Walters, D., Walsh, D., Newton, A. and Lyon, G. (2005) Induced Resistance for Plant Disease Control: Maximizing the Efficacy of Resistance Elicitors. Phytopathology, 95, 1368-1373. http://dx.doi.org/10.1094/PHYTO-95-1368

[17] Forcat, S., Bennett, H.M., Mansfield, W.J. and Grant, M.R. (2008) A Rapid and Robust Method for Simultaneously Measuring Change in the Phytohormones ABA, JA and SA in Plants Following Biotic and Abiotic Stress. Plant Methods, 4, 16. http://dx.doi.org/10.1186/1746-4811-4-16

[18] Kramell, R., Miersch, O., Schneider, G. and Wasternack, C. (1999) Liquid Chromatography of Jasmonic Acid Amine Conjugates. Chromatographia, 49, 42-46. http://dx.doi.org/10.1007/bf02467185

[19] Yoshioka, K., Nakashita, H., Klessig, D.F. and Yamaguchi, I. (2001) Probenazole Induces Systemic Acquired Resistance in Arabidopsis with a Novel Type of Action. The Plant Journal, 25, 149-157. http://dx.doi.org/10.1046/j.1365-313x.2001.00952.x

[20] Strobel, N.E. and Kuc, J.A. (1995) Chemical and Biological Inducers of Systemic Resistance to Pathogens Protect Cucumber and Tobacco Plants from Damage Caused by Paraquat and Cupric Chloride. Phytopathology, 85, 1306-1310. http://dx.doi.org/10.1094/Phyto-85-1306

[21] Segarra, G., Casanova, E., Bellido, D., Odena, M.A. Oliveira, E. and Trillas, I. (2007) Proteome, Salicylic Acid, and Jasmonic acid Changes in Cucumber Plants Inoculated with Trichoderma asperellum strain T34. Proteomics, 7, 39433952. http://dx.doi.org/10.1002/pmic.200700173

[22] Pieterse, C.M.J., Van Wees, S.C.M., Hoffland, E. and Van Pelt, J.A. (1996) Systemic Resistance in Arabidopsis Induced by Biocontrol Bacteria Is Independent of Salicylic Acid Accumulation and Pathogenesis-Related Gene Expression. The Plant Cell, 8, 1225-1237. http://dx.doi.org/10.1105/tpc.8.8.1225

[23] Saikia, R., Singh, T., Kumar, R., Srivastava, J., Srivastava, A.K., Singh, K. and Arora, D.K. (2003) Role of Salicylic Acid in Systemic Resistance Induced by Pseudomonas fluorescens against Fusarium oxysporum f. sp. ciceri in chickpea. Microbiological Research, 158, 203-213. http://dx.doi.org/10.1078/0944-5013-00202

[24] Renga, R.J., Kulothungan, S., Kumaran, E., Senthil, P.S., Arun, P. and Shanmugaraju, V. (2015) Optimization of Salicylic Acid Production by Pseudomonas fluorescens for the Control of Alternaria alternate Leaf Spot in Tomato Plant. Scrutiny International Research Journal of Agriculture, Plant Biotechnology and Bio Products, 2, 23-37.

[25] Chen, C., Belanger, R.R., Benhamou, N. and Paulitz, T.C. (1999) Role of Salicylic Acid in Systemic Resistance Induced by Pseudomonas spp. against Pythium aphanidermatum in Cucumber Roots. European Journal of Plant Pa- 
thology, 105, 477-486. http://dx.doi.org/10.1023/A:1008743502784

[26] Van Loon, L.C. (2000) Systemic Induced Resistance. In: Slusarenko, A.J., Fraser, R.S.S. and Van Loon, L.C., Eds., Mechanisms of Resistance to Plant Diseases, Springer, Dordrecht, 521-574. http://dx.doi.org/10.1007/978-94-011-3937-3_13

[27] Kunkel, B.N. and Brooks, D.M. (2002) Cross Talk between Signaling Pathways in Pathogen Defense. Current Opinion in Plant Biology, 5, 325-331. http://dx.doi.org/10.1016/S1369-5266(02)00275-3

[28] Niki, T., Mitsuhara, I., Seo, S., Ohtsubo, N. and Ohashi, Y. (1998) Antagonistic Effect of Salicylic Acid and Jasmonic Acid on the Expression of Pathogenesis-Related (PR) Protein Genes in Wounded Mature Tobacco Leaves. Plant and Cell Physiology, 39, 500-507. http://dx.doi.org/10.1093/oxfordjournals.pcp.a029397

[29] Creelman, R.A. and Mullet, J.A. (1997) Biosynthesis and Action of Jasmonates in Plants. Annual Review of Plant Physiology and Plant Molecular Biology, 48, 355-381. http://dx.doi.org/10.1146/annurev.arplant.48.1.355

[30] Akram, W., Mahboob, A. and Ali Javed, A. (2013) Bacillus thuringiensis Strain 199 Can Induce Systemic Resistance in Tomato against Fusarium Wilt. European Journal of Microbiology and Immunology, 3, 275-280. http://dx.doi.org/10.1556/EuJMI.3.2013.4.7

[31] Mur, L.A.J., Kenton, P., Atzorn, R., Miersch, O. and Wasternack, C. (2006) The Outcomes of Concentration-Specific Interactions between Salicylate and Jasmonate Signaling Include Synergy, Antagonism, and Oxidative Stress Leading to Cell Death. Plant Physiology, 140, 249-262. http://dx.doi.org/10.1104/pp.105.072348 